\title{
RF-Magnetron Sputtering of $\mathrm{Si}_{3} \mathrm{~N}_{4}$ and Study of $\mathrm{Si}_{3} \mathrm{~N}_{4} / p$-Si Heterostructures
}

\author{
V. S. Zakhvalinskii ${ }^{1}$ *, I. Yu. Goncharov', E. A. Kudryavtsev' ${ }^{1}$ E. A. Piluk ${ }^{1}$, D. A. Kolesnikov', \\ V. G. Rodriges' ${ }^{1}$, Z. A. Kabilov', S. V. Taran', and A. P. Kuzmenko² \\ ${ }^{1}$ Belgorod National Research University, Belgorod, 308015, Russia \\ ${ }^{2}$ South-West State University, Kursk, 305040, Russia
}

\begin{abstract}
Here we report the feasibility of using cheap and environmentally friendly RF-magnetron sputtering of $\mathrm{Si}_{3} \mathrm{~N}_{4}$ and formation of $\mathrm{Si}_{3} \mathrm{~N}_{4}$ nanostructured films with developed surface. $p$-Si(100) polished plates commonly used in photovoltaic structures were chosen as a substrate. $\mathrm{Si}_{3} \mathrm{~N}_{4}$ film surface morphology was studied using atomic force microscopy. It has been established that the specific surface area of the silicon nitride increases more than 10 times by increasing substrate temperature from $T_{s}=40{ }^{\circ} \mathrm{C}$ to $T_{s}=800^{\circ} \mathrm{C}$. At the same time, growth of substrate temperature changed the average size of nano-patterns. Cross section of the heterostructure $\mathrm{Si}_{3} \mathrm{~N}_{4} / p$-Si(100) was investigated by high resolution transmission electron microscopy. Based on electron diffraction studies, it was found that the obtained silicon nitride film is a mixture of cubic and amorphous phases $\mathrm{Si}_{3} \mathrm{~N}_{4}$. The $\mathrm{Si}_{3} \mathrm{~N}_{4} / \mathrm{p}-\mathrm{Si}(100)$ heterostructure is found to be similar to previously studied $\mathrm{SiC} / \mathrm{p}-\mathrm{Si}(100)$.
\end{abstract}

Keywords: RF Magnetron Sputtering. $\mathrm{Si}_{3} \mathrm{~N}_{4}$ Thin Film, Nano-Patterns, Solar Cells.

\section{INTRODUCTION}

Silicon nilride $\left(\mathrm{Si}_{3} \mathrm{~N}_{4}\right)$ is one ol the main diclectrics that are used in silicon clecironics. As compared will silicon oxide $(\varepsilon \approx 3,9)$ niltide has a higher permillivily $(\varepsilon \approx 7)$ and is uxed ax an insulating layer. Besides. $\mathrm{Mi}_{3} \mathrm{~N}_{4}$ possesses the ahility to localize (capnure traps) injected into electrons and holes with a giant lifetime in a losidized state, more than 16 years at $85^{\circ}$ 'C. Memory effeet in silicon nitride is used in the non-volatile devices (llash memory)..$^{1.2}$ lior the silicon devices most commonly used amorphous silicon nitride. In pholovollaic struclures amorphous silicon nitride is used ax an anti-reflection layer with excellent surface and bulk passivation properties. ${ }^{3}$

Silicon nitride $\mathrm{Si}_{3} \mathrm{~N}_{4}$ are yellowish crystals; polyorystalline $\mathrm{Si}_{3} \mathrm{~N}_{4}$ color varies from white to gray. It is known in lhrec modilicalions: $\alpha$ and $\beta$ are of hexagonal syngony, for $\alpha-S_{3} \mathrm{~N}_{4} a=0.7765 \mathrm{~mm}, c=0.5622 \mathrm{~nm}$, spacc group 133/c; ror $\beta-\mathrm{Si}_{3} \mathrm{~N}_{4}: a=0.7606 \mathrm{~mm}, c=0.2909 \mathrm{~nm}$, space group $\mathrm{P} 63 / \mathrm{m}: \alpha-\mathrm{Si}_{3} \mathbf{N}_{4}$ turns into $\beta$ above $1400^{\circ} \mathrm{C}$. $\beta-\mathrm{Si}_{3} \mathrm{~N}_{4}$ stable up to $\sim 1600=\mathrm{C}$. (. uhic $\gamma$ modification usually formed at high pressurex, for $\gamma-\mathrm{Si}_{3} \mathrm{~N}_{4} a=7.7418 \mathrm{~nm}$. space group $1 \mathrm{~d}-3 \mathrm{~m} . \mathrm{Si}_{3} \mathrm{~N}_{4}$ bandegp is $4.0 \mathrm{cV}$. Silicon nilride does nol react will nitric acid, sulluric acid and hydrochloric acid. slightly react with $\mathrm{II}_{3} \mathrm{PO}_{4}$ and intensively will hydrolluoric acid. Oxidation $\mathrm{Si}_{3} \mathrm{~N}_{4}$ in air starts ahove $900=C^{+}$Inicjue chemical, mechanical, electrical and optical properties of silicon nitride make it promising malerial for electronics, including pholovollaics.

Layers of $\mathrm{Si}_{3} \mathrm{~N}_{4}$ or related silicon nitride solid solutions are used in photovoltaic devices for the surface passivalion" and as anli-refleclive laycrs. ${ }^{6}$ lilcctrical passivalion is used to reduce the surlace charge carricrs recomhination in silicon wafers or films. Use of silicon nitride Irap Jeads to a sharp reduclion of carriers concentralion in the absorbing layer of the silicone waler and decreases the prohability of its recombination. $\Lambda s$ an antireflection Jayer $\mathrm{Si}_{3} \mathrm{~N}_{4}$ increases liphl absorlation. ${ }^{3}$

Particularly influential passivalion cllects should be pronounced on thin-film solar cells due to the fact that its surlace is close to the space charge renion of the $p-n$ junclion where charge scparation occurs."

In complex $p-i-n$ solar cells there were used layers of amorphous $\mathrm{Si}_{3} \mathrm{~N}_{4}$ or related silicon nitrides $S \mathrm{~N}_{y}$ and solid solutions based on $\mathrm{Si}_{3} \mathrm{~N}_{4_{-}}$, which were deposiled on the surface of the ahsorhing layer of Si emitter. In some cases. passivalion layers were deposiled belore applying a back clectrode. 3." 'There are approved pertomance improvement. of industrial photovoltaic eells after $S i_{j} N_{4}$ application passivalion laycrs ol hydrogenaled amorphous silicon nilride 
a-SiN $\mathrm{N}_{x}: \mathrm{H}$ using plasma-enhanced chemical vapor deposition (PECVI)). In many cases the addition of small amounls ol hydrogen, that is ollen used in the passivalion layers in solar cells did not significantly affect the crystal structure and electronic properlics of silicon nilride.s

For preparation of amorphous hydrogenised films there are known varieties of chemical vapor deposition technology (CVI)): hol wirc CVI) (HWCVI), hol lilamenl. CVI) (IIFCVI)) or catalytic (CVI) (Cat-CVI)) ${ }^{10} 12$ (CVD technologies are environmentally harmliul because ol the loxic chemicals used. Environmentally friendly alternatives are high lrequency magneiron spullering (Rl'-magnetron spultering) or laser ahlation ( $\mathbf{L} \Lambda$ ).

Moreover. in order to reduce the cost of solar panels it is reasonable to use the simplest single-junction struchures. ${ }^{7}$ Efficiency of solar cells could he improved by increased absorplion of the upper layer of the licicroslruclure provided by $\mathrm{Si}_{3} \mathrm{~N}_{4}$ films. The high frequency magnetron sputtering allows oblaining a homogencous, developed surlace
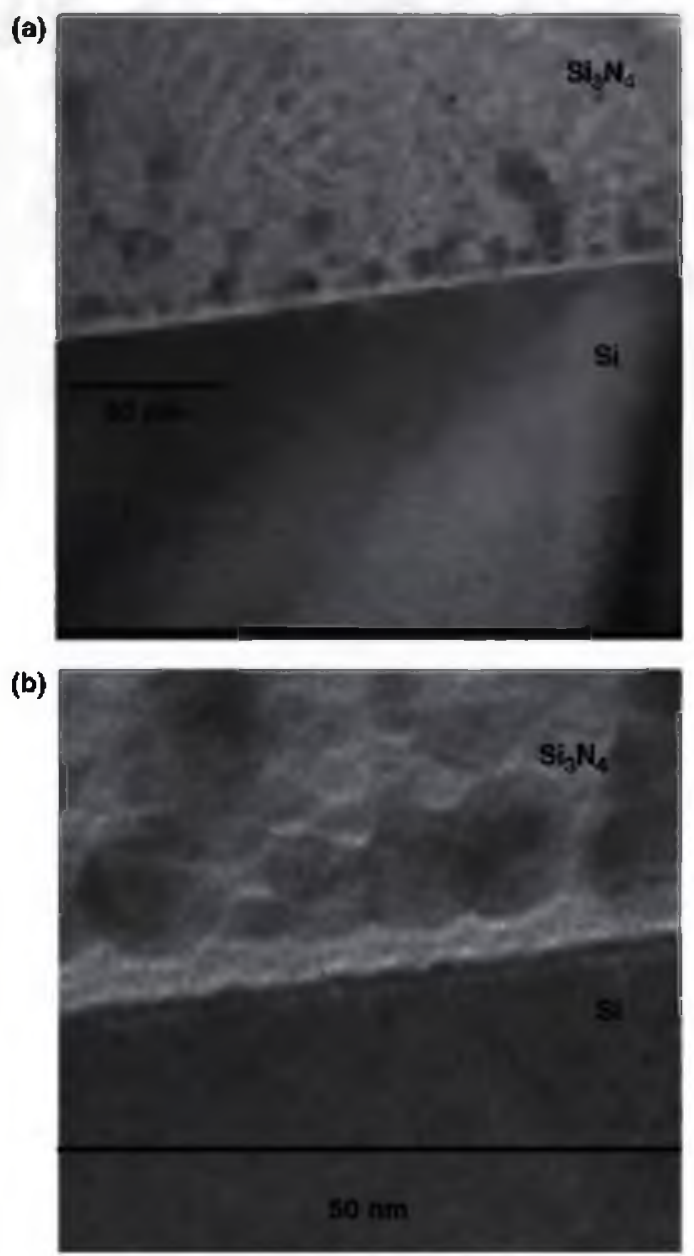

Fig. I. Findings of investigation of thin foril cross section of helarostructurs: $\mathrm{Si}_{3} \mathrm{~V}_{4} / \mathrm{Si}(100)$ in transmission sketron mixrascope (ILM). (a) Intertase owerall visw ot hetcrostructure $\mathrm{Si}_{4} \mathrm{~N}_{+} / \mathrm{Si}(100)$ (b) Compusits: mophology of $\mathrm{Si}_{3} . \mathrm{V}_{1}$ lîm cross section. of the alssorbing layer. Regime ol spullering can control surface morphology and device structure.

In this work we report the ohtaining of $\mathrm{Si}_{3} \mathrm{~N}_{4} / \mathrm{Si}(100)$ layer wilh a developed surlace and its properlies as a lunclion of preparalion procedure.

\section{EXPERIMENTAL DETAILS}

\subsection{Preparation of $\mathrm{Si}_{3} \mathrm{~N}_{4}$ Nanolayers}

'l'hin lilms of parlially amorphous nanocryslalline $\mathrm{Si}_{3} \mathrm{~N}_{4}$ were prepared by the high-Irequency non-reaclive magnetron sputtering in an $\Lambda \mathrm{r}$ atmosphere using an improved Ukrrosprihor VN-2000) semp. $\Lambda$ previously synthesized silicon nilride was used as a targel. Deposilion was carricd oul. on a polished $(100)$ plane of $p-S i$ will a resistivily ol 2 Ohm - cm. Oplical healing allowed to control the substrate temperature in the range from 40 to $800{ }^{\circ} \mathrm{C}$ It has heen found that on unintentional substrate heating

(a)

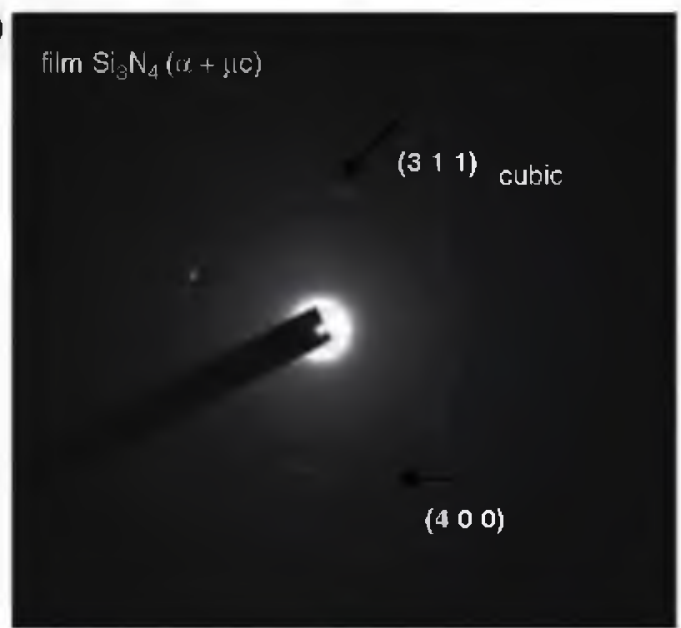

(b)

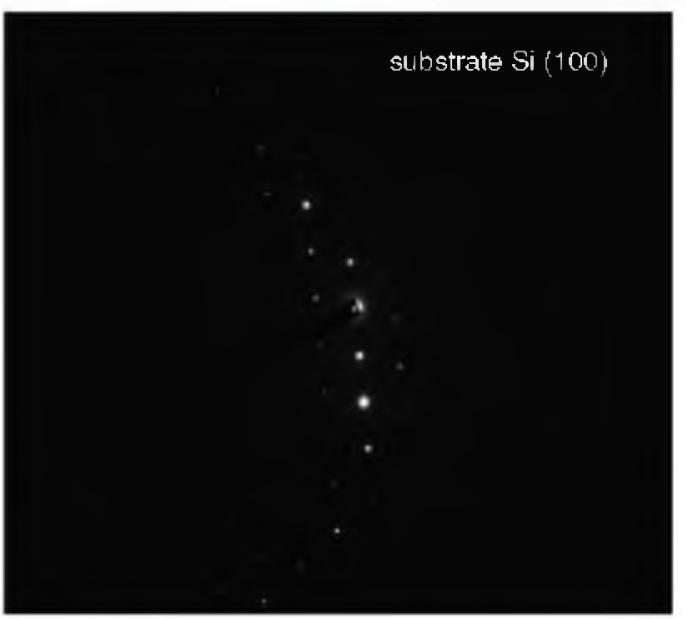

lig, 2. Lilsctron diffraction from $\mathrm{Si}, \mathrm{N}_{4} / \mathrm{Si}(100)$ hstarostructurs obtainsd in transmission alsectron microscops: (1L-M). (a) Dittissional rings around rellection diflusional center indicale dominant amosphoss nalure of the film, availability of ill-ctefined concentric rings inclicules minor phatse of nancorystallis: or fine-grainsd naturs, (b) l'or comparison thers is shown

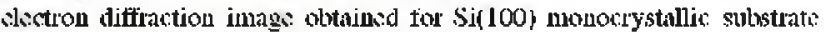
in the same helerostrukture. 


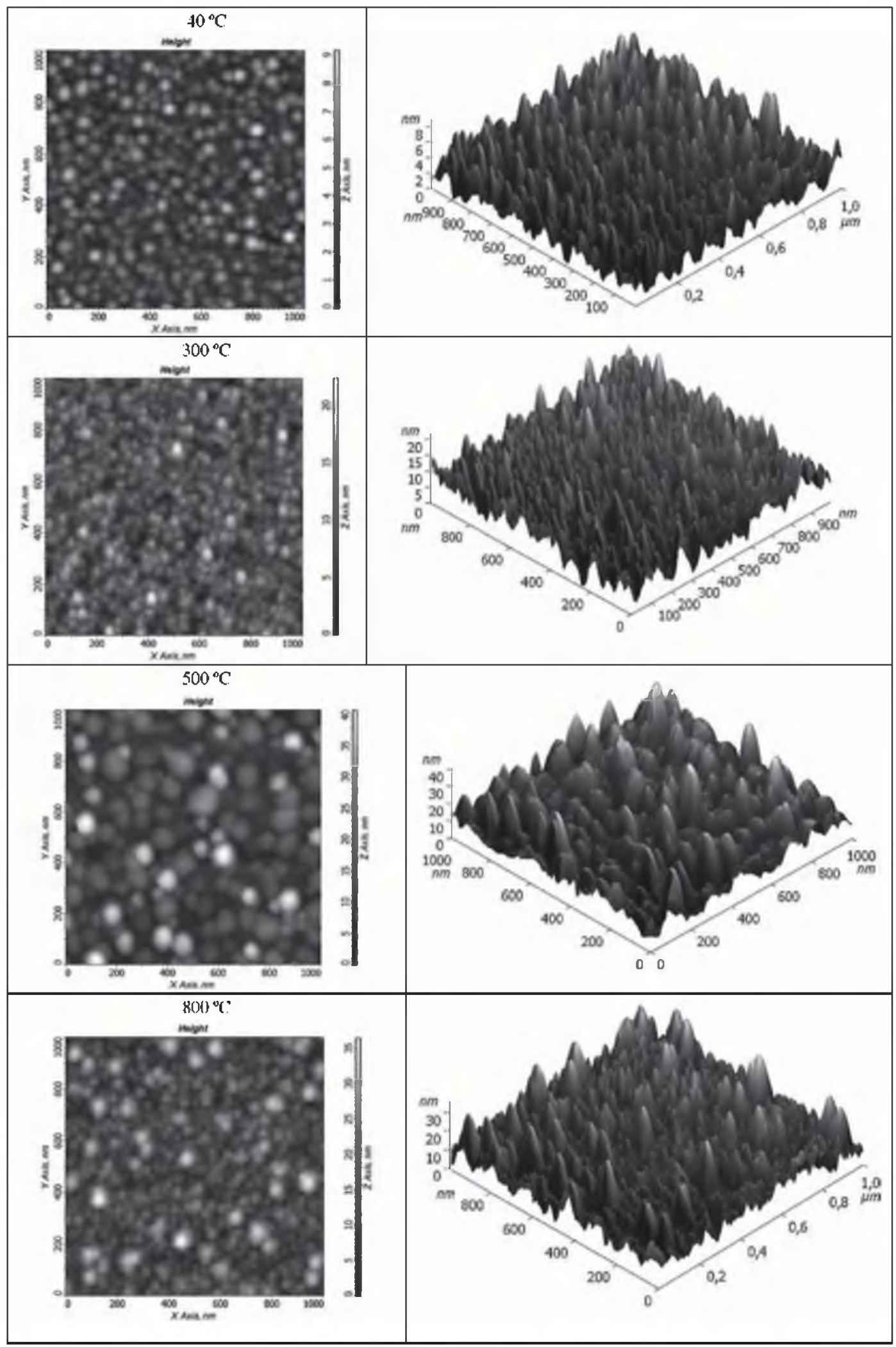

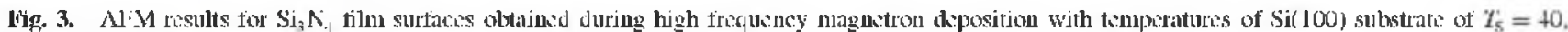
300. 500 и 800 : C. rexpectively. 

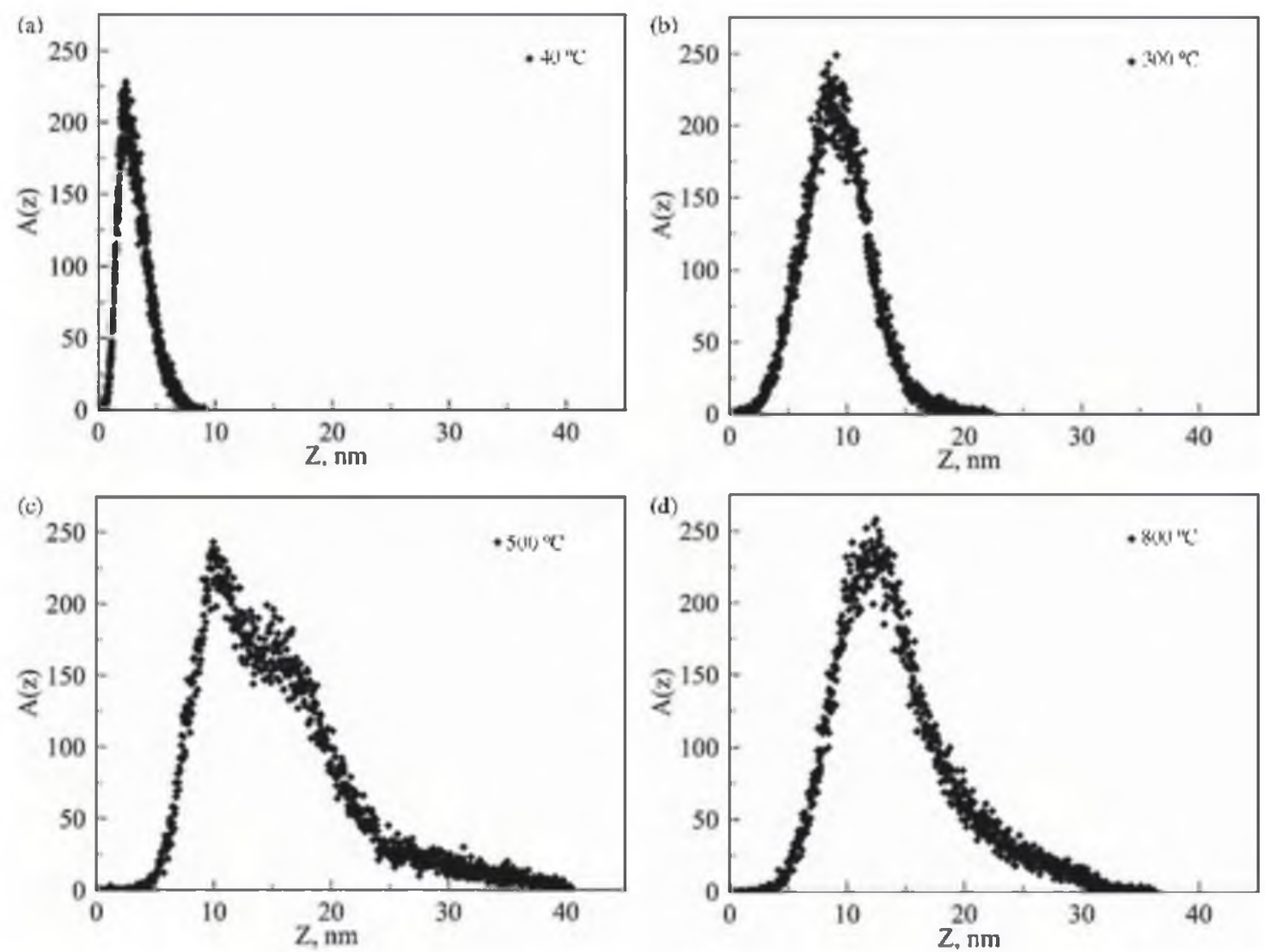

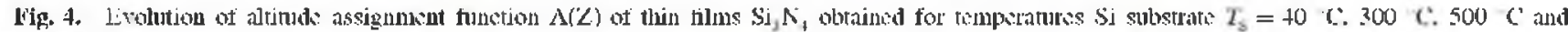
$\$ 00 \cdot C$

its temperature was about 40$)^{\prime C}$ due to interaction with the plasmia. The layer of silicon oxide was removed from Si substrate by chemical elching in HI belore the $S_{3} \mathrm{~N}_{+}$ film deposition. $S \mathrm{Si}_{3} \mathrm{~N}_{4}$ nanolayers with the thickness of about $20 \mathrm{~nm}$ have heen deposited at $40,300,500)$ and $800^{\circ} \mathrm{C}$.

\subsection{Characterization of $\mathrm{Si}_{3} \mathrm{~N}_{4}$ Nanolayers and $\mathrm{Si}_{3} \mathrm{~N}_{4} \mathrm{Si}(100)$ Heterustructure}

The vibration structure of deposited layers was characlerived by Raman spectroscopy usine co-local nanomelric resolulion Omega Scope AlS'l-N'l Raman microscope exciled wilh an $532 \mathrm{~mm} \mathrm{Ar}^{-}$laser. 'The Raman spectra

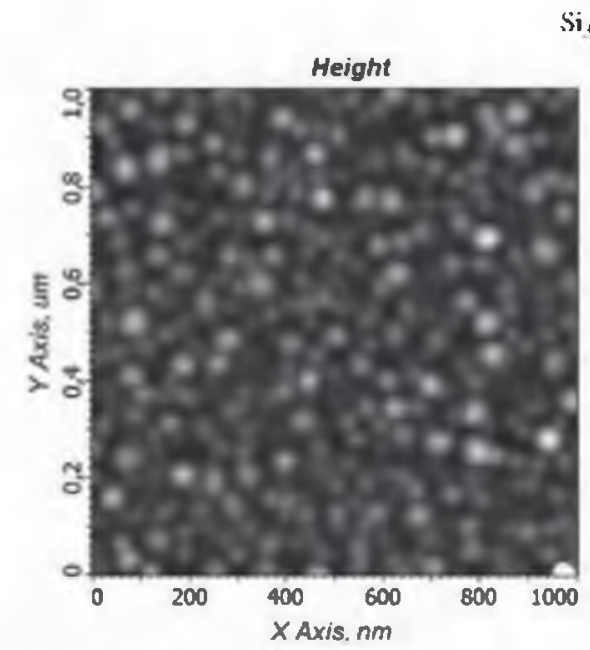

$\left.\mathrm{Si}_{4} \mathrm{~V}_{4} \mathrm{I}_{\mathrm{s}}=41\right)^{\circ} \mathrm{C}$ :

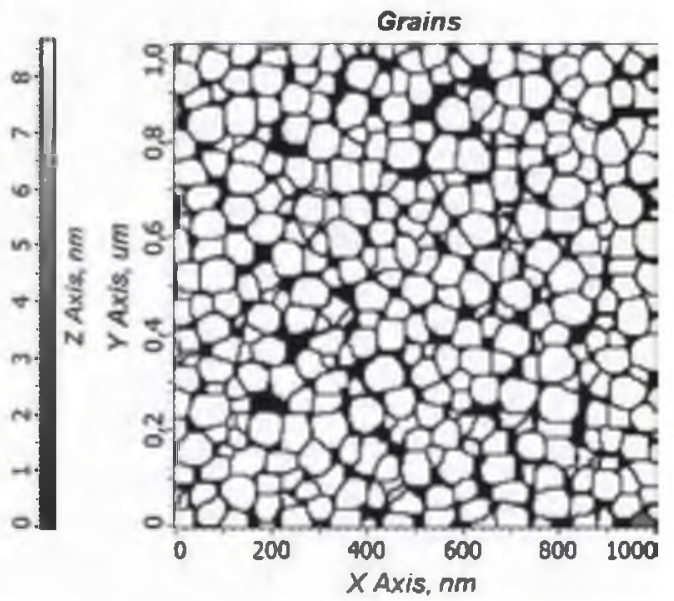

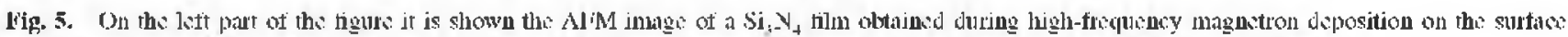

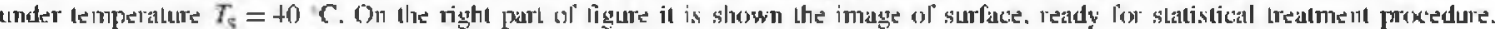



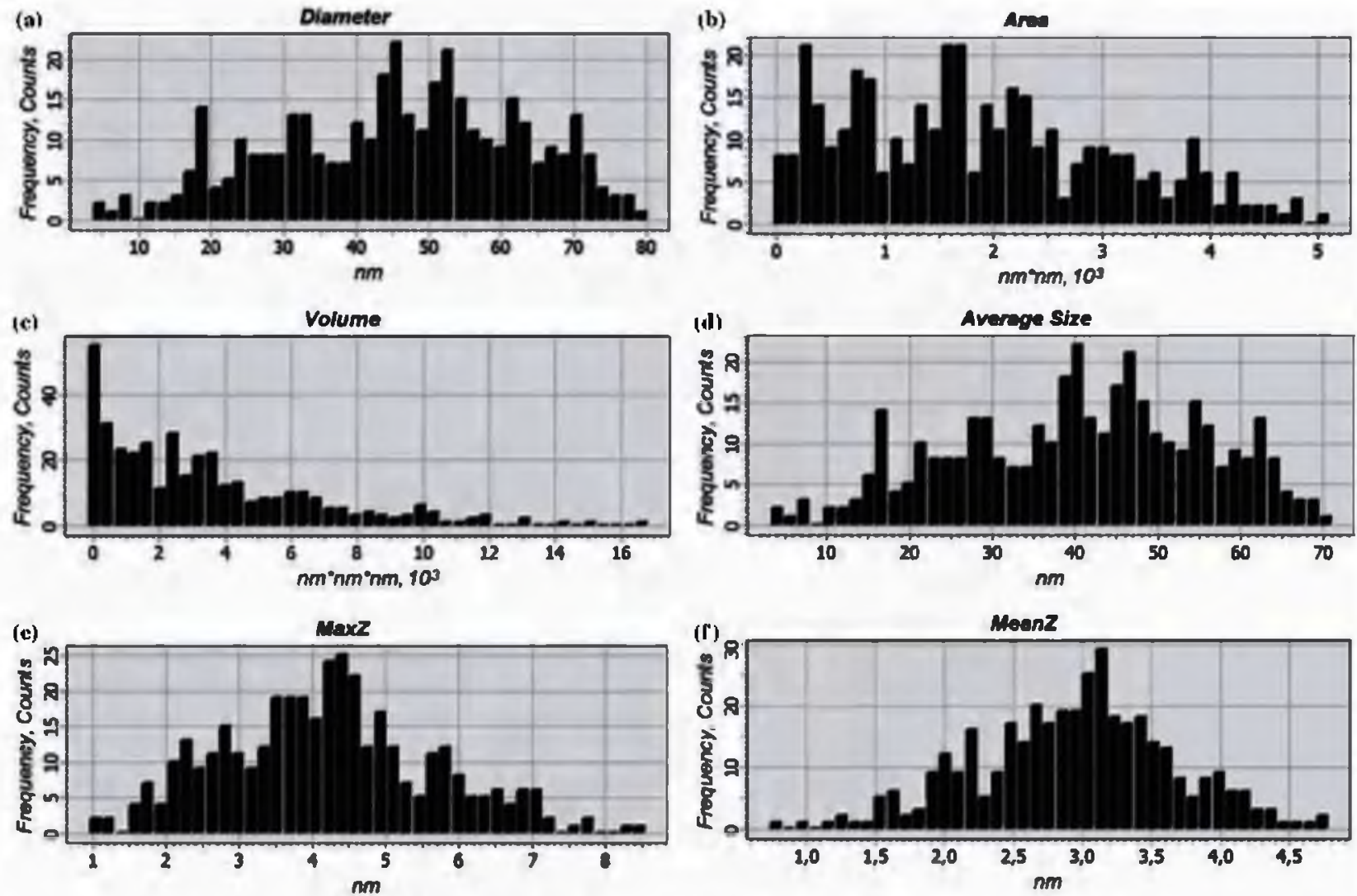

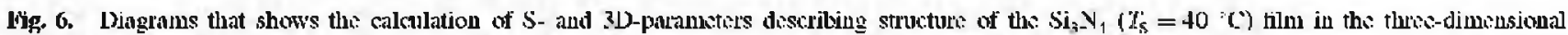
spence.

show a dominant band at $982 \mathrm{~cm}{ }^{1}$, in the spectral region characteristic for $\mathrm{Si}_{3} \mathrm{~N}_{4}{ }^{13}$

The layer surface morphology was sudied by the contact mode atomic force microscopy $(\Lambda F M)$ on Ntegra $\Lambda$ ura (NI-MI)'; Russia), using canlilevers CSGill series in a controlled atmosphere or low vacuum. 'Ithe $\mathrm{Si}_{3} \mathrm{~N}_{+}$lilm thickness was estimated by the step height al the edge of the lilm.

'The interlace belween $\mathrm{Si}_{3} \mathrm{~N}_{4}$ lilm and silicon substrate was investigalcd on cross section loils of the helerostruclure $\mathrm{Si}_{3} \mathrm{~N}_{4} / \mathrm{Si}(100)$ using the images and electron diliraction patterns ohtained on a Jeol JEM 2100 transmission electron microsiope.

\section{RESULTS AND DISCUSSION}

Investigation of the cross section of $\mathrm{Si}_{3} \mathrm{~N}_{4} / \mathrm{Si}(100)$ hedcrostruclure oblained al. a sulsstralc temperalure $\tau_{5}=40^{\circ} \mathrm{C}$. reveal a distinct houndiry hetween the $\mathrm{Si}_{3} \mathrm{~N}_{4}$ lidyer and
Si(100) (Fig, 1). From the Figure 1(b) you can see a little $\sim 1 \mathrm{~nm}$ texture that looks like parallel rows in the $\mathrm{Si}_{3} \mathrm{~N}_{4}$ lilm directed perpendicularly to the Si sulastrale. Jiggure 2 shows the results of electron beam diliraction in a Iransmission elcciron microscope. Dillision regions around the sentral diffuse reflex are typical for the amorphous material and the presence of ill-defined concentric rings indicaling the presence of secondary nanocryslalline phase (1'ig. 2(a)). Hence, the $\mathrm{Si}_{3} \mathrm{~N}_{4}$ li]m is in a mixed amorphous and nanocrystalline state $(\alpha+\mu c)$. Calculation of interplanar distances. which were made on the hasis of elestron diffraction. suggests that $\mathrm{Si}_{3} \mathrm{~N}_{4}$ nanocrystals helongs to cuhic system, space group Fd-3m. On the Figure 2(b) there is a clear piclure of symmelrical rellexes spols corresponding to the single-cryslat substrale $\operatorname{Si}(100)$.

Surlace morphology ol $\mathrm{Si}_{3} \mathrm{~N}_{4}$ li $\mathrm{ms}$ oblained al sulasiralc temperature $T_{5}=40.300 .500^{\circ}$ and $800^{\circ} \mathrm{C}$. was studied using $\Lambda F M($ Fig. 3). Distribution function of profile beight

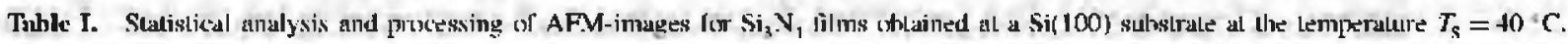

\begin{tabular}{|c|c|c|c|c|c|c|c|c|c|c|c|c|c|}
\hline & Area & $\begin{array}{l}\text { Nicrags: } \\
\text { sise }\end{array}$ & J.englh & Mean widlh & Aspect tulits & Volume & Range 7 & Max 7 & Min 7 & Mein 7. & 1.xual mean 7 , & Perimeler & Jjiameler \\
\hline I'nil & $\mathbf{n m} * \mathbf{n m}$ & $\mathbf{m m}$ & $\mathrm{nm}$ & $\sin$ & & $\mathbf{n m} * 11 \mathrm{~m} * \mathbf{n m}$ & nm & $\mathrm{mm}$ & nin & חורו & $\mathrm{mm}$ & $\mathrm{nm}$ & $\mathrm{mm}$ \\
\hline Arerage: & 1925.081 & +1.276 & 58.026 & 4 & & & 2.737 & 4.260 & 1.523 & 2.977 & 53 & 171.599 & +6.576 \\
\hline SI) & $120+.687$ & $1+.87 .5$ & 17.811 & 12.547 & 0.659 & 3152.873 & $1 .+15$ & 1.418 & 0.362 & 0.702 & 0.664 & $6+.205$ & 16.78 .5 \\
\hline
\end{tabular}


1able L. Statistical trisatment of $\mathrm{Nl}$-M-images of $\mathrm{Si}_{3} \mathrm{~V}_{+}$tilm obtained

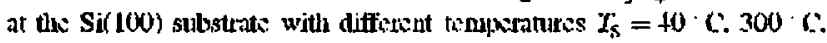
$50{ }^{\circ} \mathrm{C}$ and $800^{\circ} \mathrm{C}$.

\begin{tabular}{|c|c|c|c|c|}
\hline \multirow[b]{2}{*}{ Parametars } & \multicolumn{4}{|c|}{$r_{\mathrm{S}}$} \\
\hline & $+0 ' C^{\prime}$ & $300 \cdot c$ & $500 \cdot C^{\prime}$ & 800 s" \\
\hline$S_{z}$ Maximum puak biight. wn & 9.1 & 22.3 & 43.6 & 36.3 \\
\hline$S_{\text {. }}$ Averays roughness. $17 m$ & 1.1 & 22 & +.9 & 3.9 \\
\hline$S_{4}, R(x)$ mean square (RMS). nמ & $1 . .3$ & 2.8 & 6.3 & $\$ .1$ \\
\hline Aprage diambetor: um & 46.5 & $39.0^{3}$ & 60.6 & 38.8 \\
\hline$S_{h}$. Suctase aren ratio. 9 & 0.8 & 4.1 & 7.6 & 8.9 \\
\hline
\end{tabular}

$\Lambda(Z)$ was uxed for the mathematical destription of the surface topography. This function gives the probability that a randomly selected point has a height $Z$. Figure 4 shows the crolulion of the distribulion lunction of allitude prolite coaling $\mathrm{Si}_{3} \mathrm{~N}_{+}$al subsiralc temperalures of $40,300,500$ and 800 "C..

Slatistical processing of the Al'M images was performed using the software package "Image Analysis $P 9 "$ (NT-MDT). The software package allows to calculate $S$ parameters (a surface area) or 3D-parameters. ${ }^{14}$ characlerixing the structure in three dimensions. lixample and results of statislical processing of the oblaimed $\mathrm{Si}_{3} \mathrm{~N}_{4}$ lilm al a substrate lemperalure $\%_{\mathrm{s}}=40$ "C are prescnited in Figures 5 and 6 and Tahle $I . \Lambda$ similar statistical analysis and processing of $\Lambda F M$-images was pertormed for $\mathrm{Si}_{3} \mathrm{~N}_{4}$ films ohtained at higher suhstrate temperatures.

lirom the $\mathrm{Al} \cdot \mathrm{M}$ image analysis il was lound that the incremerl of the surlace arca $\left(S_{\mathrm{dr}}\right)$ increased from $0.8 \%$ at $T_{\mathrm{s}}=40{ }^{\circ} \mathrm{C}$ 10 $4.1,7.6$ and $8.9 \%$ at 300,500 and 800$)=\mathrm{C}$ correspondingly (lable ll). However, the average grain diameter $60 \mathrm{~nm}$ is maximal for the temperature of $500{ }^{\circ} \mathrm{C}$. The minimum diameter of the grains is about $40 \mathrm{~nm}$. which have the layers deposited at 300 and $8000^{\circ} \mathrm{C}$. Coatings at a substrale lemperalure of $40^{\circ}$ (. have the grain diancler of $45 \mathrm{~mm}$. The maximum valuc of $6 \mathrm{~mm}$ of the mean-scuare roughness $\left(S_{\mathrm{q}}\right.$ ) was lound lor a subsiralc icmperature of $500{ }^{\circ} \mathrm{C}$. The minimum $S_{4}$ value of $1 \mathrm{~nm}$ was obtained for the $\mathrm{Si}_{3} \mathrm{~N}_{4}$ film deposited at 40 : $\mathrm{C}$..

\section{CONCLUSION}

In this article, the dependence of the surface morphology of mixed $(\alpha+n c)$ amorphous and nanoxrystalline silicon nitride films $\mathrm{Si}_{3} \mathrm{~N}_{4}$ depend on temperature were investigated by atomic force microscopy method. It was lound thal the growlh substralc temperalure up $10 \% \%_{\mathrm{s}}=$ $800^{\circ} \mathrm{C}$. increases the surlace arca of the lilm (mean-square roughness $\left(S_{\mathrm{i}_{1}}\right)$ ) is more than 10 limes. In the case of silicon nitride films as ahsorhing and antireflection layers in photovoltaic structures very lerge impact on the efficiency of wolar energy conversion bas both area and surface morphology of the outer layer. Structure of cross section $\left(4+n c^{\prime}\right)$ of the $\mathrm{Si}_{3} \mathrm{~N}_{4} / p-\mathrm{Si}(100)$ beterostructure was investigated by transmission electron microscopy. It has heen lound that the $\mathrm{Si}_{3} \mathrm{~N}_{4}$ lilm has a mixed character (amorphous and nanoerystalline phase). On the basis of clectron diltraction sudics it was lound that the $\mathrm{Si}_{3} \mathrm{~N}_{4}$ nanocrystals belonged to cubic system, It. was lound that a cross scelion of $\mathrm{Si}_{3} \mathrm{~N}_{4}$ lin was complex lexure, composed of layers of ahout $1 \mathrm{~nm}$. located perpendicular to the plane of the Si suhstrate and larger ohjects up to tens of nanometers. which is consistent with the results of $\Lambda F M$ microscopy.

Acknowledgments: Research was accomplished with the support of Ministry of liducalion and Science ol the Russian liederalion, Relicrence number 367.

\section{References and Notes}

1. C.-H. T,er, K.-C. Park. and K. Kim. Afth. Phys. f.tl. 87. 0735]0 (2015)

2. K. A. Nasyrow, S. S. Shajmeev. V. A. Gricenko. G. X. Han, S. V. Kim. and (i. V. Li. ChLFY 129. 926 (200)6).

3. D.-Il. Neuhaus and $\Lambda$. Minzar. Artances in Opto Lfectronics, in special issute Volume. Arlicle T) 24521, 15 phuses (21107).

4. V. A. Critsenko, Phyxits - Thpekhi 55. 408 (2012).

5. 1. L. Cnuz-Campa. at al.. Sol Linergy Mates: Sol Cells 95. 551 (2011).

6. A. T.tinnie, H. Ahdullah. S. Shatait, and K. Sopian. Amerioun Jomonal of Apslied Srien'es 6. 20+3 (2009).

7. V. Zakhralinskii. Li. Piliuk, L, Goncharow, $\Lambda$. V. Simashkavich. D. $\Lambda$. Sharban. L. 1. Bruk. N. C'urmsi, and M. Rusu, p-Si/n-SiC nanolayser pholovollaic: aell. Protectings of the 38th Europecon Photonsilcis Solar Fnergy Comferou'e, Paris. France, Seplemler-October (2013).

8. J. Schmidt, J. L. Moschns. J. Ilsnze, S. Dauwh, and R. Ilezel. Recent progress in the surface passimation of silicon solar cells using

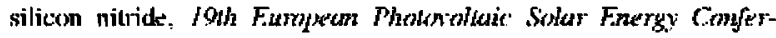
are. Paris. France. Iune (2004).

9. L. L. Llintzschs. C. M. lang. I. Watts. M. Malsman. Ci. Jordan. M. W. P. L. Lamars. A. W. Wabler and Ci. Krisse, Phrsical Reniew $B$ 86. 23520+ (2012).

10. Y. Tawada and H. Yamagishi. Sol. Fnergy Mater Sol. Cell. 66. 95 (20)1).

11. B. Kach. I. Koschek, J. Muller, \$. Wisdx. and II. Wanner. Sol Fuergy Mater. Sil. C.ells 66, 267 (20m)

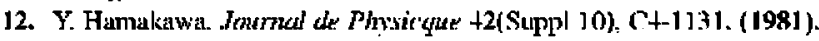

13. R. D. Munda, R d'Agostino. li liracassi. and l: Palumbro. Plasma Process. Holym. 2, 612 (2005).

14. J. Blunt and $X$. Jiang. Adyanced Techniques for Assessment Surrace Topoyraphy: Tevelopment of a Basis for 35) Surface Texture Standards "Surtstand," Kogan Pags Scisuce, London (2003). 